\title{
PENGARUH KONTROL DIRI, JENIS KELAMIN, DAN PENDAPATAN \\ TERHADAP PENGELOLAAN KEUANGAN PRIBADI MAHASISWA PASCASARJANA UNIVERSITAS NEGERI SURABAYA
}

\author{
Dwi Herlindawati, Pascasarjana Unesa \\ dwi.herlindawati@yahoo.com
}

\begin{abstract}
ABSTRAK
Penelitian ini bertujuan untuk menganalisis pengaruh kontrol diri, jenis kelamin, dan pendapatan terhadap pengelolaan keuangan pribadi mahasiswa Pascasarjana Universitas Negeri Surabaya baik secara parsial maupun simultan. Penelitian yang dilakukan merupakan penelitian kuantitatif. Populasi dalam penelitian ini mahasiswa Pascasarajana Universitas Negeri Surabaya angkatan tahun 2014 sebanyak 910 dengan jumlah sampel sebanyak 278 mahasiswa yang terdiri atas 128 mahasiswa dan 150 mahasiswi. Metode analisis data menggunakan teknik analisis regresi linier berganda. Hasil penelitian menunjukkan bahwa secara parsial kontrol diri dan pendapatan berpengaruh signifikan terhadap pengelolaan keuangan pribadi mahasiswa Pascasarjana Universitas Negeri Surabaya, sedangkan jenis kelamin tidak memiliki pengaruh terhadap pengelolaan keuangan pribadi mahasiswa Pascasarjana Universitas Negeri Surabaya. Secara simultan kontrol diri, jenis kelamin, dan pendapatan berpengaruh signifikan terhadap pengelolaan keuangan pribadi mahasiswa Pascasarjana Universitas Negeri Surabaya.
\end{abstract}

Kata Kunci: Kontrol diri, jenis kelamin, pendapatan, pengelolaan Keuangan Pribadi

\begin{abstract}
This study aimed to analyze the influence of self-control, gender, and income on personal financial management Universitas Negeri Surabaya Post Graduate student either partially or simultaneously. Research conducted a quantitative study. The population in this study are Post Graduate students of Universitas Negeri Surabaya in 2014 as many as 910 with a total sample of 278 students consisting of 128 male students and 150 female students. Methods of data analysis using multiple linear regression analysis technique. The results showed that partially self-control and earnings significantly influence personal financial management of Post Graduate student Universitas Negeri Surabaya, while gender has no influence on personal financial management of Post Graduate student Universitas Negeri Surabaya. Simultaneously self-control, gender, and income significantly influence personal financial management of Post Graduate student Universitas Negeri Surabaya.

Keywords: Self control, Gender, Income, Personal Financial Management
\end{abstract}




\section{PENDAHULUAN}

Era globalisasi yang membawa peningkatan serta pertumbuhan perekonomian seluruh negara-negara di dunia, tak terkecuali Indonesia memberikan dampak terhadap perilaku keuangan mayarakat Indonesia dalam memenuhi kebutuhannya. Sebagai manusia yang tidak terlepas dari kebutuhan dan keinginan yang tidak terbatas inilah yang terkadang menjadi salah satu faktor penyebab seseorang bergaya hidup konsumtif. Pola hidup konsumtif yang tidak sesuai dengan pendapatan yang dimilki dengan perilaku konsumsi mereka dapat menyebabkan kegagalan financial.

Hal tersebut juga terjadi pada beberapa mahasiswa Pascasarjana Universitas Negeri Surabaya, bahwa mahasiswa ini kurang memperhatikan pengelolaan keuangan mereka sehingga memungkinkan terjadinya kegagalan keuangan mereka. Dengan kondisi tersebut tentu sangat diperlukan kemampuan para mahasiswa dalam mengelola keuangan pribadi mereka, agar mereka bisa mengatur dan mengelola antara pendapatan yang didapat dengan pengeluaran yang sudah dianggarkan. Menurut Cude, et all (2006), bahwa diperlukan pengetahuan tentang bagaimana mengelola keuangan serta bagaimana teknik berinvestasi menjadi hal yang tidak dapat diabaikan lagi seperti masa sebelumnya, dimana perkembangan instrumen keuangan masa modern ini ternyata tidak dibarengi oleh keinginan masyarakat untuk memulai berinvestasi atau menabung. Menurut Malinda (2007) pengelolaan keuangan pribadi adalah sebuah proses pencapaian tujuan pribadi melalui manajemen keuangan yang terstuktur dan tepat. Giltman (2004) manajemen keuangan pribadi merupakan seni dan ilmu mengelola sumber daya keuangan dari unit individu. Menurut Senduk (2004) ada lima ranah pendekatan dalam mengelola keuangan pribadi yaitu: (1) membeli dan memiliki sebanyak mungkin harta produktif, (2) mengatur pengeluaran, (3) berhati-hati dengan hutang, (4) menyisihkan untuk masa depan, dan (5) memiliki proteksi.

Saat ini masyarakat lebih memilih pola hidup konsumtif dari peningkatkan pendapatannya, dan tidak dibarengi dengan pengendalian keinginan untuk mengisvestasikan atau menabung sebagian kelebihan keuangan mereka sebagai cara pengelolaan keuangan pribadi dalam menunjang tercapainya kesejahteraan hidup baik di masa sekarang dan di masa depan. Pembelian suatu barang/jasa tidak lagi untuk memenuhi kebutuhan melainkan keinginan, hal tersebut merupakan gejala-gejala yang mengindikasikan adanya kecenderungan perilaku konsumtif. Kontrol diri yang kurang dalam membelanjakan penghasilan adalah menjadi salah satu penyebab sebagian besar individu membelanjakan semua penghasilannya tanpa memikirkan keuangan untuk jangka panjang.

Temuan dilapangan juga mengatakan bahwa mahasiswa di Surabaya, khususnya mahasiswa Pascasarjana Universitas Negeri Surabaya sering sekali mengunjungi pusat-pusat perbelanjaan seperti Mall atau departemen store. Hal ini dikarenakan beberapa hal salah satunya karena didukung oleh banyaknya Mall di daerah Surabaya, yang juga seringkali memberikan potongan-potongan harga baik untuk kebutuhan sehari-hari, pakaian dan makanan. Hal tersebut kadang membuat para mahasiswa lupa diri dan tidak mengontrol keinginan belanja mereka. Penelitian yang dilakukan Otto, et al (2007) bahwa dalam konteks keuangan, kontrol diri merupakan sebuah aktifitas yang dapat berfungsi mendorong seseorang melakukan penghematan (tujuan yang bermanfaat) serta dapat menekan 
pembelian implusif (tujuan untuk kesenangan semata). Chaplin (2002) mendefinisikan kontrol diri merupakan kemampuan membimbing tingkah laku sendiri, berkaitan dengan kemampuan seseorang menekan atau menghambat tingkah laku yang implusif.

Menurut beberapa penelitian pengaruh perbedaan jenis kelamin terhadap pengelolaan keuangan pribadi dapat menjadi salah satu faktor yang mempengaruhi seorang individu dalam membuat keputusan keuangannya. Salah satunya menurut penelitian yang dilakukan Astari dan Widagda (2014) bahwa gender yaitu dalam prespektif perbedaaan jenis kelamin pria dan wanita mempengaruhi atas suatu pengelolaan keuangan pribadi. Dimana pria cenderung lebih rasional dalam membelanjakan uang dibanding wanita yang lebih banyak didasarkan pada faktor-faktor kesenangan semata. Penelitian yang dilakukan Kusumowidagdo (2010) mengemukakan bahwa perbedaan jenis kelamin berpengaruh terhadap kontrol perilaku belanja seseorang, dimana pria merupakan pebelanja utilitarian (berdasarkan manfaat) sedangkan wanita kebanyakan merupakan pebelanja hedonis (kesenangan semata). Sehinga membelanjakan pendapatan untuk barang/jasa yang lebih bermanfaat tentu akan sangat mempengaruhi pengelolaan keuangan pribadi menjadi lebih baik. Menurut penelitian yang dilakukan Lusardi dan Mitchel (2007) menemukan bahwa pria cenderung memiliki tingkat pengetahuan keuangan pribadi yang lebih baik dan luas dibanding perempuan, sehingga pria cenderung lebih baik dalam mengambil keputusan keuangan dalam mengelola keuangan pribadi mereka dibanding wanita. Dengan pengetahuan keuangan yang lebih baik tentu hal tersebut mempengaruhi pola pikir dan pengambilan keputusan keuangan atas perilaku belanja yang lebih terencana berdasarkan anggaran yang telah dibuat sebelumnya, sehingga pengelolaan keuangan pribadi yang tepat akan dapat terwujud.

Namun ada beberapa penelitian yang mengemukakan bahwa perbedaan jenis kelamin tidak mempengaruhi pengelolaan keuangan mereka dalam hal keputusan membeli atau membelanjakan pendapatan mereka. Penelitian Hadjali, et al (2012) mengatakan bahwa bahwa jenis kelamin, lingkungan belanja, petunjuk penjualan, individualism dan harga tidak mememiliki pengaruh terhadap pengelolaan keuangan pribadi seseorang dalam mengatur pengeluarannya/keputusan membeli. Penelitian lain yang senada adalah penelitian Semuel (2007) menunjukkan bahwa uang saku, usia, dan jenis kelamin tidak memberikan pengaruh terhadap pengelolaan keuangan pribadi seseorang dalam mengatur pengeluarannya/keputusan membeli suatu produk. Dalam penelitian ini yang digunakan sebagai indikator perbedaan jenis kelamin adalah perbedaan secara biologis pria dan wanita.

Temuan lain yang juga didapat pada mahasiswa Pascasarjana Universitas Negeri Surabaya adalah mengenai tingkat pendapatan yang diperoleh oleh mahasiswa Pascasarjana. Beberapa mahasiswa ini memperoleh tambah pendapatan dari uang saku beasiswa, dimana per mahasiswa minimal menerima Rp 1.500.000,00/bulan. Dari penambahan pendapatan tersebut harusnya sudah dapat dikategori ke dalam tingkat pendapatan yang tinggi, namun dari hasil observasi di lapangan ditemukan bahwa beberapa mahasiswa pascasarjana yang mendapatkan tambahan dana dari beasiswa ini mengatakan pendapatan yang didapat tersebut belum dapat mencukupi kebutuhan hidup mereka seluruhnya. 
Bahkan ada beberapa diantara mereka yang berasal dari kota yang dekat dengan kota Surabaya rela tidak kost dengan konsekuensi pulang pergi setiap hari saat ada jadwal perkuliahan, hal tersebut dilakukan dengan alasan untuk menghemat biaya hidup. Hal tersebut tentu menimbulkan tanya, mengapa adanya penambahan pendapatan tidak disertai dengan ketepatan pengelolaan keuangan mereka untuk dapat memenuhi kebutuhan hidup.

Pendapatan dapat memiliki arti yang bermacama-macam, tergantung dari sisi mana untuk meninjau pengertian pendapatan tersebut. Pada penelitian ini akan fokus pada pendapatan yang dihasilkan oleh perorangan atau pribadi. Pendapatan dapat didefinisikan sebagai jumlah seluruh uang yang diterima oleh seseorang atau rumah tangga selama jangka waktu tertentu (biasanya satu tahun). Pendapatan dapat berupa upah/gaji, atau penerimaan tenaga kerja, pendapatan dari kekayaan seperti sewa, bunga dan deviden, serta pembayaran transfer atau penerimaan dari pemerintah seperti tujangan sosial (misal beasiswa) atau asuransi pengangguran. Menurut pendapatan adalah jumlah penghasilan yang diterima oleh penduduk atas prestasi kerjanya selama satu periode tertentu, baik harian, mingguan, bulanan ataupun tahunan. Dalam hubungannya dengan pengelolaan keuangan seseorang, menurut penelitian yang dilakukan Hilgert et al (2003) bahwa responden yang berpendapatan tinggi lebih tepat waktu dalam melaporkan pembayaran tagihan-tagihan mereka dibandingkan dengan orang yang berpendapatan rendah. Keown (2011) berkenaan dengan tingkat kekayaan, tingkat pendapatan seseorang diasosiasikan dengan tingkat literasi keuangannya, bahwa seseorang yang memiliki pendapatan lebih tinggi cenderung memiliki tingkat pengetahuan keuangan yang lebih tinggi sehingga mendukung pengelolaan keuangan yang lebih baik.

Dengan demikian, tujuan dalam penelitian ini antara: (a) Menganalisis pengaruh kontrol diri, jenis kelamin, dan pendapatan terhadap pengelolaan keuangan pribadi mahasiswa Pascasarjana Universitas Negeri Surabaya secara parsial: (b) ) Menganalisis pengaruh kontrol diri, jenis kelamin, dan pendapatan terhadap pengelolaan keuangan pribadi mahasiswa Pascasarjana Universitas Negeri Surabaya secara simultan.

\section{METODE PENELITIAN}

Penelitian ini tergolong penelitian kuantitatif. Penelitian ini menggunakan tiga variabel bebas yaitu kontrol diri $\left(\mathrm{X}_{1}\right)$, jenis kelamin $\left(\mathrm{X}_{2}\right)$, dan pendapatan $\left(\mathrm{X}_{3}\right)$, serta satu variabel terikat yaitu pengelolaan keuangan pribadi (Y). Tujuan penelitian ini adalah pengujian hipotesis, yaitu penelitian yang menjelaskan fenomena yang terjadi dalam bentuk hubungan antar variabel untuk mencari pengaruh antara variabel bebas (independen) yaitu kontrol diri $\left(\mathrm{X}_{1}\right)$, jenis kelamin $\left(\mathrm{X}_{2}\right)$, dan pendapatan $\left(\mathrm{X}_{3}\right)$ terhadap variabel terikat (dependen) yaitu pengelolaan keuangan pribadi (Y). Desain penelitian ditunjukkan dalam bagan di bawah ini: 


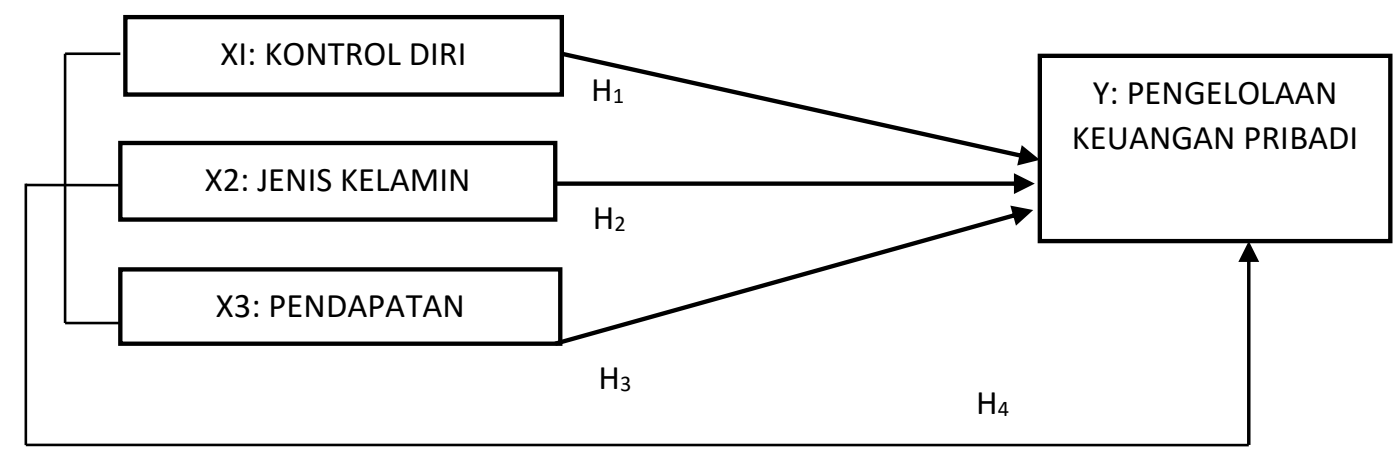

Gambar 1. Desain Penelitian

Populasi dalam penelitian ini adalah seluruh mahasiswa Pascasarjana Universitas Negeri Surabaya angkatan tahun 2014 sebanyak 910 siswa, yang terdiri atas 419 mahasiswa dan 491 mahasiswi. Sedangkan teknik pengambilan sampel dalam penelitian ini menggunakan proportionate random sampling yaitu teknik pengambilan anggota sampel dari populasi dilakukan secara acak dengan memperhatikan proporsi yang ada dalam populasi itu. teknik pengambilan sampel dengan mempertimbangkan unsur-unsur dalam populasi penelitian (Sugiyono, 2010). Sehingga sampel yang diperoleh adalah 278 siswa yang terdiri atas 128 mahasiswa dan 150 mahasiswi.

Metode pengumpulan data yang digunakan dalam penelitian ini adalah observasi, dokumentasi dan angket. Metode dokumentasi digunakan untuk memperoleh data penelitian di lapangan berupa dokumen-dokumen yang berisikan jumlah mahasiswa Pascasarjana Universitas Negeri Surabaya angkatan tahun 2014 secara keseluruhan, per kelas per program studi, serta status pembiayaan kuliah mahasiswa (berbeasiswa/regular). Angket atau kuesioner digunakan untuk mengumpulkan data primer atas variabel kontrol diri, jenis kelamin pendapatan dan pengelolaan keuangan pribadi mahasiswa. Sedangkan metode observasi dilakukan peneliti untuk mendapatkan data secara langsung mengenai karateristik populasi dan keadaan dari para responden serta dapat mendukung hasil yang diperoleh dari angket. Teknik analisis data yang digunakan adalah analisis regresi linier berganda.

Analisis regresi linier berganda ini menggunakan uji asumsi klasik (Ghozali, 2005) diantaranya yang digunakan dalam penelitian ini adalah uji normalitas, uji multikolinier, uji heteroskedastisitas, dan uji linieritas. Terdapat dua uji statistik yang digunakan dalam penelitian ini yaitu uji t dan uji F. Uji t digunakan untuk mengetahui ada atau tidaknya pengaruh kontrol diri $\left(\mathrm{X}_{1}\right)$, jenis kelamin $\left(\mathrm{X}_{2}\right)$, pendapatan $\left(\mathrm{X}_{3}\right)$ secara parsial terhadap pengelolaan keuangan pribadi (Y). Uji $\mathrm{F}$ digunakan untuk mengetahui ada atau tidaknya kontrol diri $\left(\mathrm{X}_{1}\right)$ jenis kelamin $\left(\mathrm{X}_{2}\right)$, pendapatan $\left(\mathrm{X}_{3}\right)$ secara simultan terhadap pengelolaan keuangan pribadi $(\mathrm{Y})$.

\section{HASIL PENELITIAN DAN PEMBAHASAN}

Berdasarkan hasil uji normalitas dengan menggunakan Kolmogrov-Smirnov didapat nilai sebesar 0,200 atau sebesar 20\%. Tingkat signifikansi tersebut lebih dari 5\% yang berarti residual mengikuti distribusi normal. Sehingga kontrol diri $\left(\mathrm{X}_{1}\right)$, pendapatan $\left(\mathrm{X}_{3}\right)$ dan pengelolaan keuangan pribadi $(\mathrm{Y})$ berdistribusi normal. Untuk uji multikolinieritas untuk nilai tolerance kontrol diri $\left(\mathrm{X}_{1}\right)$ sebesar 0,944 
dan pendapatan $\left(\mathrm{X}_{3}\right)$ sebesar 0,944. Dan untuk nilai VIF tolerance kontrol diri $\left(\mathrm{X}_{1}\right)$ sebesar 1,060 dan pendapatan $\left(\mathrm{X}_{3}\right)$ sebesar 1,060 dari ketiga variabel bebas mempunyai nilai $\mathrm{VIF}<10$ atau kurang dari 10 , artinya kedua variabel bebas (independent) yaitu kontrol diri dan pendapatan tidak terdapat hubungan multikolinearitas sehingga dapat digunakan untuk memprediksi pengelolaan keuangan pribadi mahasiswa Pascasarjana Universitas Negeri Surabaya. Sedangkan untuk uji Heterokedastistas menggunakan korelasi glejser pada masing-masing variabel bebas menghasilkan $\mathrm{p}>0,05$. Untuk kontrol diri $\left(\mathrm{X}_{1}\right)$ sebesar 0,970 dan pendapatan $\left(\mathrm{X}_{3}\right)$ sebesar 0,234. Hal ini berarti tidak terjadi heterokedastisitas sehingga variabel kontrol diri dan pendapatan dapat digunakan sebagai variabel yang mempengaruhi pengelolaan keuangan pribadi mahasiswa Pascasarjana Universitas Negeri Surabaya. Dan untuk uji linieritas diperoleh nilai deviation from linearity antara kontrol diri $\left(\mathrm{X}_{1}\right)$ memiliki hubungan linier dengan pengelolaan keuangan pribadi $(\mathrm{Y})$ sebesar 0,0570 dan pendapatan $\left(\mathrm{X}_{3}\right)$ memiliki hubungan linier dengan pengelolaan keuangan pribadi (Y) sebesar 0,138.

Berdasarkan uji signifikansi yang telah dilakukan maka model persamaan regresi dapat ditulis dalam bentuk persamaan regresi linier berganda sebagai berikut : $Y=32,626+0,327 X_{1}+0,944 X_{3}+$ ei

Berdasarkan uji hipotesis pertama, diperoleh hasil uji-t bahwa kontrol diri memiliki nilai signifikansi $0.000<0.05$. Dimana kontrol diri berpengaruh positif terhadap pengelolaan keuangan mahasiswa, sehingga dapat didiskripsikan bahwa semakin baik kontrol diri maka semakin baik pula pengelolaan keuangan pribadi mahasiswa. Diperlihatkan melalui koefisien regresi variabel kontrol diri $\left(\mathrm{X}_{1}\right)$ sebesar 0,327, artinya setiap perubahan variabel kontrol diri $\left(\mathrm{X}_{1}\right)$ akan berpengaruh positif terhadap pengelolaan keuangan pribadi (Y) sebesar 0,327 dengan asumsi variabel pendapatan $\left(\mathrm{X}_{3}\right)$ tidak mengalami perubahan atau konstan.

Hasil penelitian ini didasarkan pada pengertian kontrol diri yang diungkapkan oleh para ahli, seperti Delisi dan Bergh (2006) mengemukakan bahwa kontrol diri berkaitan dengan tindakan seseorang untuk mengendalikan dan menghambat secara otomatis kebiasaan, dorongan, emosi atau keinginan dengan tujuan untuk mengarahkan perilakunya. Sedang dalam konteks keuangan menurut Nofsinger (2005) mengatakan bahwa seseorang mengontrol pengeluarannya dengan melawan keinginan atau dorongan untuk membelanjakan uang secara berlebihan atau dengan kata lain membelanjakan uang berdasarkan keinginan bukan kebutuhan, sehingga kontrol diri berhubungan dengan mengelola keuangan secara lebih baik. Pada dasarnya dalam sebuah pengelolaan keuangan menuntut pribadi setiap individu memiliki pola hidup yang memiliki prioritas sehingga akan terhindar dari pola hidup konsumtif dan pemborosan.

Pada penelitian ini didipatan hasil secara umum mean semua indikator untuk variabel kontrol diri dikategorikan tinggi dalam mempengaruhi pengelolaan keuangan pribadi mahasiswa. Hal ini ditunjukkan dari mean jawaban responden pada angket kontrol diri yaitu diperoleh rata-rata mean sebesar 3,025 yang berada interval 3,00 - 4,00 dengan kategori tinggi. Secara berurutan jawaban responden dengan mean tertinggi adalah pada indikator mengkaji ulang pengeluaran yaitu 3,16. Kemudian pada indikator pengendalian emosi dengan mean 3,07. Mean indikator kontrol implus/dorongan adalah 3,01. Dan urutan terakhir Mean indikator kemampuan berpikir rasional yaitu 2,86. Hal ini berarti bahwa 
mahasiswa Pascasarjana Universitas Negeri Surabaya rata-rata memiliki kontrol diri dalam pengelolaan keuangan yang tinggi.

Temuan dalam penelitian ini didukung oleh penelitian-penelitian sebelumnya yang dilakukan oleh Henutesa (2012) yang menemukan bahwa PNS di lingkup Pemerintahan Rote Ndao yang memiliki kontrol perilaku dan sifat berhati-hati (conscientiousness) dalam keuangan akan berpengaruh yang signifikan terhadap niat mereka melakukan kontrol diri dalam mengelola keuangan pribadi. Adrie dkk (2014) dalam penelitiannya juga menemukan bahwa seseorang yang memiliki kontrol diri dan sifat berhati-hati (conscientiousness) dalam keuangan akan mempengaruhi niat dan perilaku seseorang dalam mengelola keuangan pribadi mereka. Dalam penelitiannya, Otto, Davies \& Chater (2007) menyimpulkan bahwa kontrol diri dalam hal pengelolaan keuangan merupakan sebuah aktivitas yang mendorong seseorang untuk melakukan penghematan dengan menurunkan pembelian impulsif (pengeluaran yang berdasarkan keinginan bukan kebutuhan).

Berdasarkan uji hipotesis yang kedua diperoleh hasil uji-t bahwa jenis kelamin memiliki nilai signifikansi 0,051 > 0,050, yang artinya jenis kelamin tidak berpengaruh terhadap pengelolaan keuangan pribadi mahasiswa. Nilai koefisien regresi variabel jenis kelamin $\left(\mathrm{X}_{2}\right)$ sebesar $-1,088$, hal ini berarti setiap perubahan variabel jenis kelamin $\left(\mathrm{X}_{2}\right)$ akan berpengaruh negatif atau hubungan yang berkebalikan terhadap pengelolaan keuangan pribadi (Y) yaitu semakin tinggi perbedaan jumlah jenis kelamin yang diteliti maka semakin tidak berpengaruh dengan pengelolaan keuangan pribadi mahasiswa sebesar -1,088 dengan asumsi variabel jenis kelamin $\left(\mathrm{X}_{2}\right)$ dan pendapatan $\left(\mathrm{X}_{3}\right)$ tidak mengalami perubahan atau konstan. Hasil yang menunjukkan tidak adanya pengaruh variabel jenis kelamin $\left(\mathrm{X}_{2}\right)$ terhadap variabel pengelolaan keuangan pribadi $(\mathrm{Y})$ inilah yang membuat variabel jenis kelamin tidak masuk ke dalam persamaan regresi linier berganda yang telah dikemukan di atas.

Dari hasil temuan penelitian di lapangan dari pengisian angket oleh para responden dapat terlihat, bahwa baik mahasiswa pria atau wanita Pascasarajana Universitas Negeri Surabaya tidak terdapat perbedaan sikap yang cukup jauh dalam pengelolaan keuangan pribadi mereka. Pada beberapa pernyataan negatif didapati jawaban yang tidak mencerminkan pengelolaan keuangan pribadi yang baik dimana responden pria dan wanita memperlihatkan hasil presentasi jawaban yang hampir sama. Contoh pada pernyataan negatif, saya berhutang untuk menutup kekurangan sumber dana utama, didapatkan hasil jawaban pada opsi jawaban setuju sebesar 27\% atau sebanyak 75 responden dengan komposisi 32 responden pria dan 43 dijawab oleh responden wanita. Pernyataan lain yaitu saya selalu mencatat semua pengeluaran yang terjadi, didapatkan hasil jawban yang lebih banyak pada opsi jawaban tidak setuju sebesar 38,8\% atau sebanyak 108 responden dengan komposisi 62 responden pria dan 50 dijawab oleh responden wanita.

Temuan dalam penelitian ini didukung oleh penelitian-penelitian sebelumnya yang dilakukan oleh Hadjali, Salimi, dan Masoumeh (2012) di Malaysia bahwa jenis kelamin tidak mememiliki pengaruh terhadap pengelolaan keuangan pribadi seseorang. Begitu pula penelitian yang dilakukan Semuel (2007) menunjukkan bahwa uang saku, usia, dan jenis kelamin tidak memberikan pengaruh terhadap 
pengelolaan keuangan pribadi seseorang dalam mengatur pengeluarannya/ keputusan membeli suatu produk.

Berdasarkan uji hipotesis ketiga, diperoleh hasil uji-t bahwa tingkat pendapatan memiliki nilai signifikansi $0.000<0.050$, yang artinya pendapatan berpengaruh positif terhadap pengelolaan keuangan pribadi mahasiswa. Sehingga dapat didiskripsikan bahwa semakin tinggi tingkat pendapatan mahasiswa maka semakin baik pula pengelolaan keuangan pribadinya. Diperlihatkan melalui koefisien regresi variabel pendapatan $\left(\mathrm{X}_{3}\right)$ sebesar 0,944 , artinya setiap perubahan variabel pendapatan $\left(\mathrm{X}_{3}\right)$ akan berpengaruh positif terhadap pengelolaan keuangan pribadi (Y) sebesar 0,944 dengan asumsi variabel kontrol diri $\left(\mathrm{X}_{1}\right)$ tidak mengalami perubahan atau konstan.

Hasil penelitian ini didukung oleh penelitian-penelitian terdahulu diantaranya yang dilakukan oleh Hilgert et al. (2003) bahwa seorang individu dengan pendapatan lebih rendah kurang mungkin melaporakan pembayaran tagihan mereka tepat waktu (melakukan pencatatan pengelolaan keuangan) dibandingkan dengan pendapatan yang lebih tinggi. Penelitian lain yang mendukung adalah penelitian Aizcorbe et al. (2003) menemukan bahwa seseorang yang memiliki pendapatan semakin besar akan memiliki perilaku manajemen keuangan yang lebih bertanggung jawab.

Mahasiswa Pascasarjana Universitas Negeri Surabaya yang rata-rata telah bekerja dan memiliki pendapatan pribadi ternyata lebih bertanggung jawab untuk mengatur pengeluaran dan kebutuhan hidup. Hal ini tentu saja berpengaruh positif terhadap pengelolaan keuangan pribadi, karena dari tingkat pendapatan yang mereka miliki membuat mereka lebih berpikir rasional untuk mengelola keuangan pribadi mereka. Dimana semakin tinggi pendapatan seseorang membuat mahasiswa memiliki pengelolaan keuangan pribadi yang lebih baik pula.

Hasil uji-t yang telah dikemukakan diatas secara lengkap dapat dilihat dalam tabel di bawah ini sebagai berikut:

Tabel 1. Hasil Uji t

\begin{tabular}{|c|c|c|c|c|c|c|}
\hline \multicolumn{7}{|c|}{ Coefficients $^{a}$} \\
\hline & \multirow[b]{2}{*}{ Model } & \multicolumn{2}{|c|}{ Unstandardized Coefficients } & \multirow{2}{*}{$\begin{array}{c}\text { Standardized } \\
\text { Coefficients } \\
\text { Beta }\end{array}$} & \multirow[b]{2}{*}{$\mathrm{t}$} & \multirow[b]{2}{*}{ Sig. } \\
\hline & & $\mathrm{B}$ & Std. Error & & & \\
\hline \multirow[t]{4}{*}{1} & (Constant) & 32.626 & 2.347 & & 13.900 & .000 \\
\hline & Kontrol Diri & .327 & .065 & .285 & 4.992 & .000 \\
\hline & Jenis Kelamin & -1.088 & .554 & -.109 & -1.963 & .051 \\
\hline & Pendapatan & .944 & .272 & .198 & 3.471 & .001 \\
\hline
\end{tabular}

Sumber : Data diolah, (2015)

Berdasarkan uji hipotesis keempat, diperoleh hasil uji-f bahwa kontrol diri, jenis kelamin dan pendapatan secara simultan berpengaruh positif pengelolaan keuangan pribadi mahasiswa Pascasarjana Universitas Negeri Surabaya dengan nilai signifikansi $0.000<0.05$. Nilai koefisien determinasi $\left(\mathrm{R}^{2}\right)$ diketahui bahwa nilai R-square adalah 0.160. Hal ini menunjukkan bahwa pengelolaan keuangan pribadi mahasiswa Pascasarjana Universitas Negeri Surabaya dipengaruhi oleh 
kontrol diri, jenis kelamin dan pendapatan sebesar 16\%, sedangkan $84 \%$ dipengaruhi oleh variabel-variabel lain di luar variabel yang diteliti.

Hasil penelitian ini didukung oleh hasilpenelitian terdahulu yaitu penelitian oleh Laksmita dan Widagda (2014) bahwa secara simultan kontrol diri dan jenis kelamin bersama-sama mempengaruhi pengelolaan keuangan pribadi seseorang dalam keputusannya membeli suatu barang tertentu misalnya parfum. Hal ini dapat berarti secara berasama kontrol diri, jenis kelamin dan pendapatan mahasiswa Pascasarajana Universitas Negeri Surabaya mempengaruhi pengelolaan keuangan pribadi mereka meski dengan nilai kontribusi yang kecil yaitu $16 \%$ yang dikateorikan rendah.

Hasil Uji F yang telah dikemukakan diatas secara lengkap dapat dilihat dalam tabel di bawah ini sebagai berikut:

Tabel 2. Hasil Uji F

ANOVA $^{\mathrm{a}}$

\begin{tabular}{|cc|c|c|c|c|c|}
\hline & & & & Mean & & \\
& Model & Sum of Squares & $\mathrm{df}$ & Square & $\mathrm{F}$ & Sig. \\
\hline 1 & Regression & 1108.800 & 3 & 369.600 & 17.446 & $.000^{\mathrm{b}}$ \\
& Residual & 5804.682 & 274 & 21.185 & & \\
& Total & 6913.482 & 277 & & & \\
\hline
\end{tabular}

a. Dependent Variable: Pengelolaan Keungan Pribadi

b. Predictors: (Constant), Pendapatan, Jenis Kelamin, Kontrol Diri

Sumber : Data diolah, (2015)

Nilai koefisien determinasi $\left(\mathrm{R}^{2}\right)$ yang telah dikemukakan diatas secara lengkap dapat dilihat dalam tabel di bawah ini sebagai berikut:

Tabel 3. Koefisien Determinasi

\begin{tabular}{l|r|r|r|r|}
\hline Model & $\mathrm{R}$ & $\mathrm{R}$ Square & Adjusted R Square & $\begin{array}{c}\text { Std. Error of the } \\
\text { Estimate }\end{array}$ \\
\hline 1 & $.400^{\mathrm{a}}$ & .160 & .151 & 4.60271 \\
\hline
\end{tabular}
$\begin{aligned} & \text { a. Predictors: (Constant), Pendapatan, Jenis Kelamin, kontrol diri } \\
& \text { Sumber: Data diolah, (2015) }\end{aligned}$

\section{SIMPULAN}

Berdasarkan hasil penelitian, dapat disimpulkan bahwa: 1) Kontrol diri terbukti berpengaruh signifikan positif terhadap pengelolaan keuangan pribadi mahasiswa Pascasarjana Universitas Negeri Surabaya. Artinya kontrol diri yang tinggi mahasiswa Pascasarjana Universitas Negeri Surabaya dalam hal keuangan akan menunjang keberhasilan pengelolaan keuangan pribadi setiap individu khususnya pada mahasiswa Pascasarjana Universitas Negeri Surabaya. Hasil temuan pada penelitian ini adalah perilaku pengelolaan keuangan pribadi 
mahasiswa Pascasarjana Universitas Negeri Surabaya diberi dukungan paling besar oleh kontrol afektif dan kontrol psikomotoriknya. Meskipun aspek kontrol kognitif yaitu kemampuan berpikir rasional mahasiswa dalam membuat keputusan keuangannya berada pada kategori sedang namun mereka sudah dapat berpikir rasional untuk mengetahui akibat positif dan negatif dari perilaku konsumtif mereka. 2) Jenis kelamin tidak berpengaruh dan berhubungan negatif terhadap pengelolaan keuangan pribadi mahasiswa Pascasarjana Universitas Negeri Surabaya. Hal ini menunjukkan bahwa secara parsial semakin tinggi perbedan jumlah jenis kelamin pada mahasiswa Pascasarjana Universitas Negeri Surabaya maka semakin tidak mempengaruhi pengelolaan keuangan pribadi mahasiswa dan mahasiswi Pascasarjana Universitas Negeri Surabaya. Hasil temuan pada penelitian ini adalah baik mahasiswa maupun mahasiswi memiliki perilaku yang tidak jauh berbeda dalam hal keuangan, sehingga perilaku pengelolaan keuangan pribadi mahasiswa pria dan wanita Pascasarjana Universitas Negeri Surabaya juga tidak menunjukkan adanya perbedaan yang signifikan. 3) Pendapatan secara parsial berpengaruh signifikan dan positif terhadap pengelolaan keuangan pribadi mahasiswa Pascasarjana Universitas Negeri Surabaya, artinya semakin tinggi tingkat pendapatan yang dimiliki seseorang akan berpengaruh positif dengan membuat setiap individu lebih baik dalam mengelola keuangan pribadinya khususnya pada mahasiswa Pascasarjana Universitas Negeri Surabaya. Hasil temuan dalam penelitian ini adalah mahasiswa yang berpendapatan lebih besar cenderung lebih sering melakukan pencatatan dan penganggaran keuangan mereka sebagai bentuk mengelola keuangan pribadi yang baik dan dapat dipertanggungjawabkan. 4) Pengaruh kontrol diri, jenis kelamin, dan pendapatan mahasiswa terhadap pengelolaan keuangan pribadi mahasiswa Pascasarjana Universitas Negeri Surabaya adalah signifikan. Hal ini menggambarkan bahwa ketiga variabel bebas tersebut memiliki peran membentuk perilaku pengelolaan keuangan pribadi yang baik bagi mahasiswa Pascasarjana Universitas Negeri Surabaya.

Berdasarkan simpulan penelitian, maka disarankan: 1) Para mahasiwa Pascasarjana Universitas Negeri Surabaya dapat lebih meningkatkan kemampuan kontrol diri dalam penggunaan keuangaan mereka, sehingga pola konsumtif dapat diminimalkan dan kegagalan finansial dimasa sekarang dan masa yang akan datang dapat terhindarkan. 2) para mahasiwa Pascasarjana Universitas Negeri Surabaya dapat lebih menyesuaikan pendapatan mereka dengan pengeluaran sesuai dengan kemampuan keuangan mereka demi tercukupinya seluruh kebutuhan hidup sehari-hari dan biaya yang harus dikeluarkan selama kuliah maupun untuk dimasa yang akan datang. 3) Terdapat variabel bebas yang menunjukkan tidak mempengaruhi variabel terikat, hal ini mungkin saja terjadi dikarenakan responden yang diambil kurang beragam karateristiknya (misal: tingkat pendidikan, tingkat pendapatan, kebiasaan, lingkungan sosial), berada satu lingkup yakni pada lingkungan mahasiswa Pascsarajana Universitas Negeri Surabaya saja. Untuk penelitian berikutnya mungkin dapat dilakakukan penelitian pada responden pada ruang lingkup dengan karateristik yang lebih beragam lagi. 


\section{DAFTAR RUJUKAN}

Adrie P., Sri H., Ari P. 2014. Perilaku Pengendalian Diri pada Perilaku Manajemen keuangan Personal Berdasarkan pada Teori Planned Behavior Menggunakan Pendekatan Partial Least Square. Journal \& Proceeding Fakultas Ekonomi \& Bisnis. UNSOED. Vol 3.12013

Aizcorbe, Ana M., Arthur B. Kennickell, dan Kevin B. Moore. 2003. Recent Changes in U.S Family Finances: Evidence from the 1998 and 2001 Survey of Consumer Finances. Federal Reserve Bulletin. 89 (Januari), pp. $1-32$

Anggun, Trisna, Damayanti. 2014. Hubungan Antara Kontrol Diri dengan Perilaku Konsumtif Membeli Pakaian Diskon pada Mahasiswi Fakultas Hukum Universitas Sriwijaya Palembang. Tesis. Diplubikasikan. Universitas Bina Darma Palembang

Astari, Laksmita W., dan Widagda K, I Gusti Ngurah Jaya A. 2014. Pengaruh Perbedaan Jenis Kelamin dan Kontrol diri terhadap Keputusan Pembelian Implusif Produk Parfum. Jurnal Manajemen Universitas Udaya, Vol. 3, No. 3, hlm. 546 - 560

Chaplin, J.P. 2002. Kamus Lengkap Psikologi. Jakarta: Raja Grafindo Persada

Delisi, M., Berg, T. 2006. Exploring Theoritical Linkages Between Self-Control Theory and Criminal Justice System Processing. Journal of Criminal Justice, 34, pp. 153-163

Ghozali, Imam. 2005. Aplikasi Analisis Multivariate dengan Program SPSS. Semarang: Badan Penerbit Universitas Diponegoro

Hadjali, Hamid Reza., Meysam Salimi, Masoumeh Sadat A. 2012. Exploring Main Factors Affecting On Impulse Buying Behaviors. Journal of American Sains, 8 (1), pp. 245-251

Henutesa, Victoria Haning. 2012. Perilaku Self-control dalam Mengelola Keuangan Pribadi: Berdasarkan Theory of Planned Behavior dan Conscientiousness. Tesis. Dipublikasikan. Salatiga: Universitas Kristen Satya Wacana

Hilgert, Marianne A., Jeanne M. Hogarth, Sondra Beverly. 2003. Household Financial Management: The Connection between Knowledge and Behavior. Federal Reserve Bulletin. 89 (7), hlm. 309 - 322

Keown, L.A. 2011. The financial knowledge of Canadians. Canadian Social Trends, Vol. 11, No. 008, pp. 30 - 39

Kusumowidagdo, Astrid. 2010. Pengaruh Desain Atmosfer Toko Terhadap Perilaku Belanja: Studi Atas Pengaruh Gender Terhadap Respon Pengunjung Toko. Jurnal Manajemen Bisnis, Vol. 3, No. 1, hal: 17 - 32.

L. Giltman. 2004. Princile of finance. Prectice Hall: New Jersey

Lusardi, A., Mitchell, O. 2007. Financial Literacy and Retirement Planning: New Evidence from the Rand American Life Panel. MRRC Working Paper, 157, pp. $1-33$ 
Malinda, Maya. 2007. Perencanaan Kuangan Pribadi. Yogyakarta: ANDI

Nofsinger, J.R. 2005. Social Mood and Financial Economics. Journal of Behavioral Finance, Vol. 6, pp. 101 - 112

Otto, Philip E, Davies G.B., Chater, N. 2007. Note on Ways of Saving: Mental Mechanisms as Tools for Self-Control?. Global Business and Economic Review, Vol. 9, No. 2

S. Senduk. 2004. Siapa Bilang Jadi Karyawan Ngak Bisa Kaya; Lima Kiat Praktis Mengelola Gaji Agar Bisa Kaya. Jakarta: Elex Media Komputindo

Semuel, Hatane. 2007. Pengaruh Stimulus Media Iklan, Uang Saku, Usia Dan Gender Terhadap Kecenderungan Perilaku Pembelian Impulsif (Studi Kasus Produk Pariwisata). Jurnal Manajemen Pemasaran, 2(1), hal: 31-42

Sugiyono. (2010). Metode Penelitian Kuantitatif Kualitatif dan $R \&$ D. Alfabeta: Bandung 